Vol-4, Issue-2, 2020 (IJEBAR)

E-ISSN: 2614-1280 P-ISSN 2622-4771

https://jurnal.stie-aas.ac.id/index.php/IJEBAR

\title{
RELATIONSHIP BRAND CHARACTERISTICS, COMPANY CHARACTERISTICS AND CONSUME R-BRAND CHARACTERISTICS WITH BRAND LOYALTY (Case Study of Sarimi Consumers in Samarinda)
}

\author{
Yoshua Pandapotan Siringoringo1), M. Jacky Murdani2) \\ 1,2Faculty of Economics and Business Mulawarman University 1 \\ Email:joshuaringo91@gmail.com1,jackymurdani28@gmail.com2
}

\begin{abstract}
:
This study is to determine the relationship between brand characteristics, company characteristics and consumer-brand characteristics with brand loyalty to Sarimi customers in Samarinda. The technique of collecting data in this study was by collecting a questioner. The types of data used in this study are primary and secondary data. The number of samples in this study were 100 people who are Sarimi consumers. Data obtained using the validity and reliability test, as well as the Spearman trial with the SPS S program. Brand Characteristics, Company Characteristics and Consumer-Brand Characteristics have a significant and strong relationship with Brand Loyalty.

Keywords: Brand Characteristics, Company Characteristics, Consumer-Brand Characteristics, Brand Loyalty
\end{abstract}

\section{Introduction}

Instant noodles are flour-based foods. Instant noodles are produced as practical food in the way they are processed and can be stored for a long time. Along with the development of the era of instant noodles have been considered to be fast food and even as a staple food for some people. So that quality and customer satisfaction are the main goals of instant noodle producers so that customers remain loyal to the brand of instant noodles that are produced. In Indonesia the development of instant noodles shows its progress, as evidenced by the emergence of instant noodle producers and the widespread circulation of instant noodle brands in the community. This research determines to find out the relationship between Brand Characteristics, Company Characteristics, Consumer-Brand Characteristics on Brand Loyalty.

\section{Theoretical Review}

\section{Brand Trust}

Brand Trust is the willingness of customers to lead to a brand and ignore the risk due to the expectation that the brand can provide positive benefits (Agustina, DH, \& Nuralam, 2018). Brand Trust has a relationship with customer satisfaction. Trust is a belief that arises from customer expectations and experiences that have been felt by customers. If customer expectations state the product and brand are good, then the customer believes that the product and brand are good (Almadea, 2017). Trust is the desire to rely on other parties to face risks. This willingness comes from the understanding of others based on their past experiences (Lau \& Lee, 1999).

Brand is a name, term, sign, symbol, or design (or combination) intended to identify the seller's goods or services, and to distinguish them from competitors. Understanding the brand is divided into six levels (SA, 2008):

1. Brands as attributes, brands are reminiscent of certain attributes.

2. Brand as a benefit, a brand is more than a set of attributes, customers don't buy attributes but they buy benefits. 
International Journal of Economics, Business and Accounting Research (IJEBAR)

Peer Reviewed - International Journal

Vol-4, Issue-2, 2020 (IJEBAR)

E-ISSN: 2614-1280 P-ISSN 2622-4771

https://jurnal.stie-aas.ac.id/index.php/IJEBAR

3. The brand as a value, the brand states something about the value of the product, the value of producers or brand holders, and customer value.

4. Brand as culture, brand has a role to represent certain culture.

5. Brand as personality, brand reflects certain personality.

6. The brand as the user, the brand can indicate the type of consumer who buys or uses the product.

In their research, Lau and Lee proposed that three sets of factors influence trust in a brand. These three sets of factors are the brand itself, the company behind the brand, and the consumers who interact with the brand. And it is also proposed that trust in a brand will lead to brand loyalty. The framework of this research is shown in the following figure proposed by (Lau \& Lee, 1999):

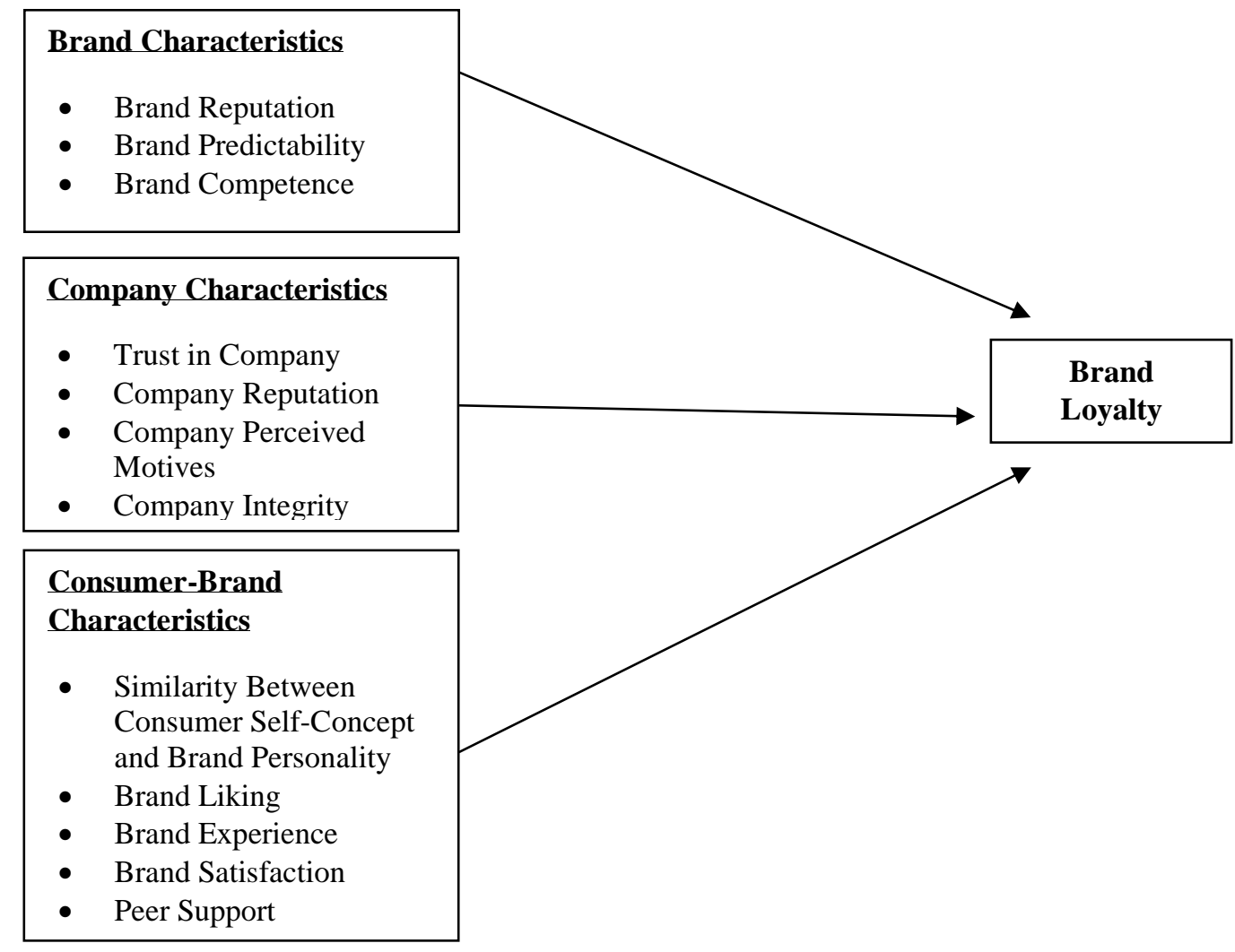

\section{Brand Characteristics}

Brand characteristics determine whether consumers decide to trust them.

\section{Brand Reputation}

Brand reputation refers to the opinion of others that the brand is good and reliable. Brand reputation can be developed through advertising and public relations, but it is also likely to be influenced by product quality and performance (Lau \& Lee, 1999). Development of brand reputation means more than just keeping consumers satisfied, it is something that companies get from time to time and refers to how various audiences evaluate brands (Veloutsou \& Moutinho, 2009). If a brand does not have a good reputation, consumers are more likely to be suspicious. From consumer awareness, they may be sensitive to any defects that the brand has. This makes it more difficult for brands to be trusted.

\section{Brand Predictability}

Predictable brands are brands that allow brand users to anticipate, with reasonable confidence, how they perform at every opportunity of use (Lau \& Lee, 1999). 
International Journal of Economics, Business and Accounting Research (IJEBAR)

Peer Reviewed - International Journal

Vol-4, Issue-2, 2020 (IJEBAR)

E-ISSN: 2614-1280 P-ISSN 2622-4771

https://jurnal.stie-aas.ac.id/index.php/IJEBAR

Predictability also depends on product attributes and brand value. When a consumer predicts about a brand while being used by other consumers, then he shows that he predicts about the product (Afzal, Khan, \& Rehman, 2010). Brand predictability increases confidence because consumers know that unexpected things will not happen when used.

\section{Brand Competence}

A competent brand is a brand that has the ability to solve consumer problems and to meet their needs. Consumers can find out about the competence of a brand through direct use or word of mouth communication (Afzal et al., 2010) . Buyers can find out the brand after using or hearing from others. When the customer feels that the brand can meet the needs, then he can be involved in purchasing decisions.

\section{H1: Brand characteristics have significant effect on brand loyalty}

\section{Company Characteristics}

The characteristics of the company behind the brand can influence the level of consumer confidence in the brand.

\section{Trust in Company}

When an entity is trusted, smaller entities underneath tend to also be trusted. Thus consumers who put their trust in companies tend to trust their brands (Lau \& Lee, 1999).

\section{Company Reputation}

If the company behind a brand is known to be fair, consumers will feel safer in obtaining and using the brand of the company (Lau \& Lee, 1999).

\section{Company Perceived Motives}

(Doney \& Cannon, 1997) identify intentionality as one of the ways in which trust is developed in buyer and seller relationships. Intentionality refers to the interpretation and judgment of one party and the motives of the other party. When consumers consider the company behind a good brand and act in the best interests of consumers, consumers will trust the brand (Lau \& Lee, 1999).

\section{Company Integrity}

The company's integrity behind a brand is consumers' perception that the brand adheres to a set of acceptable principles, such as keeping promises, being ethical, and being honest. If the company behind a brand has integrity, the brand might be trusted by consumers (Lau \& Lee, 1999).

\section{H2: Company characteristics have significant effect on brand loyalty}

\section{Consumer-Brand Characteristics}

Relationships of both parties affect in a relationship. Thus the characteristics of consumer brands can affect consumer confidence in a brand.

\section{Similarity Between Consumer Self-Concept and Brand Personality}

Research in interpersonal relationships shows that the similarity of characteristics between two parties can provide a tendency to believe. If the physical or personality attributes of a brand are judged to be similar with consumers' self-images, consumers tend to trust them (Lau \& Lee, 1999).

\section{Liking Brand}

Liking shows a certain preference that one party has towards another party because the other party finds the other party pleasant. So that consumers can build relationships with a brand, consumers must like the brand first. When consumers like a brand, consumers will be bound to find out more about the brand and can trust it (Lau \& Lee, 1999).

\section{Brand Experience}

Brand experience refers to consumers' encounters with brands in the past, especially in the field of use. As consumers gain more experience with a brand, consumers can 
International Journal of Economics, Business and Accounting Research (IJEBAR)

Peer Reviewed - International Journal

Vol-4, Issue-2, 2020 (IJEBAR)

E-ISSN: 2614-1280 P-ISSN 2622-4771

https://jurnal.stie-aas.ac.id/index.php/IJEBAR

understand the brand better and grow to trust it more. This experience is not limited to positive experiences, because any experience increases the ability of consumers to predict brand performance (Lau \& Lee, 1999).

\section{Brand Satisfaction}

Brand satisfaction is defined as cumulative satisfaction as an overall consumer evaluation based on total consumer purchases and experience with brand products or services (Grisaffe \& Nguyen, 2011). When a consumer is satisfied with a brand after using it, this situation is similar to fulfilling a promise. Because the brand has kept its promise, consumers can trust it more (Lau \& Lee, 1999).

\section{Peer Support}

Displacement is one of the ways in which trust is developed (Doney \& Cannon, 1997) . Transference is an extension of trust in a party based on a third party's definition of trust. Through transfer, the trust given to others in a brand will be 'transferred' from them to other consumers. Therefore, consumers tend to trust brands that are trusted by others. Indirectly they get the approval and support of co-workers for their next actions (Lau \& Lee, 1999).

\section{H3: Consumer brand characteristics have significant effect on brand loyalty}

\section{Brand Loyalty}

Brand loyalty is an attractive focal point for researchers and marketing practitioners. Previous research indicates that loyal customers spend more than customers of non-loyal, acting as an advocate for a brand to engage mouth to mouth and positive, and therefore "at the heart of customer groups most valuable company" (Ganesh, Arnold, \& Reynolds 2000). Brand loyalty refers to the behavior of consumers who repeatedly buy certain brands over a certain period of time. This is based on past behavior, and local consumers are very likely to buy products from certain brands now and in the future (Wang, $\mathrm{Wu}, \&$ Lin, 2000).

Brand loyalty in general can be measured in ways as beriku $\mathrm{t}$ (Dharmmesta, 1999):

1. Brand-choice sequence (brand-choice sequence)

2. Proportion of purchase (proportion of purchase)

3. Brand preferences (brandpreference)

4. Commitment brand (brand commitment)

\section{Options Brand Sequence}

The brand choice sequence method or called the repurchase pattern, products that are often bought by consumers can be used as objects to facilitate measurement (Dharmmesta, 1999). For example, if A, B, C, D, E, and F are brands in a particular group, the four categories of brand loyalty can be explained in the following purchase sequence:

1. Loyalty is not separated (undivided loyalty), shown by the AAA A AA series.

2. Loyalty is divided (divided loyalty), shown by the $\mathrm{ABABAB}$ sequence.

3. Unstable loyalty, indicated by the AAABBB series.

4. No loyalty (no loyalty), indicated by the ABCDEF sequence.

\section{Proportion of Purchases}

The advantage of this method compared to the brand choice sequence (Dharmmesta, 1999) is (1) it is easier to be quantified, (2) it allows identification of multiple brand loyalty. For example, the loyalty of two brands shows the proportion of purchases aimed at two brands in a certain group; loyalty of three brands, aimed at three brands, and so on. 
International Journal of Economics, Business and Accounting Research (IJEBAR)

Peer Reviewed - International Journal

Vol-4, Issue-2, 2020 (IJEBAR)

E-ISSN: 2614-1280 P-ISSN 2622-4771

https://jurnal.stie-aas.ac.id/index.php/IJEBAR

\section{Brand Preferences}

Brand loyalty is considered a "positive attitude" towards a certain product, often described in terms of the intention to buy. This approach shows that the positive attitude of consumers towards a brand has become the basis for an understanding of brand loyalty (Dharmmesta, 1999).

\section{Brand Commitment}

The existence of brand loyalty raises a commitment to a brand. Brand commitment usually occurs in products with involvement that symbolize the self-concept, values, and needs of consumers (Dharmmesta, 1999).

Previous Research

\begin{tabular}{|c|c|c|c|c|c|}
\hline No & $\begin{array}{l}\text { Author / } \\
\text { year }\end{array}$ & Title & $\begin{array}{l}\text { Conclusions / } \\
\text { Research } \\
\text { Results }\end{array}$ & Difference & Equation \\
\hline 1 & $\begin{array}{l}\text { Zahra } \\
\text { Idrees, Xia } \\
\text { Xinping, } \\
\text { Khuram } \\
\text { Shafi, Lui } \\
\text { Hua and } \\
\text { Anna } \\
\text { Nazeer } \\
(2015)\end{array}$ & $\begin{array}{l}\text { "Consumer's } \\
\text { Brand Trust } \\
\text { and It's Link to } \\
\text { Brand Loyalty" }\end{array}$ & $\begin{array}{l}\text { The results } \\
\text { showed that } \\
\text { Brand Trust } \\
\text { contributes } \\
\text { positively to } \\
\text { Brand Loyalty. }\end{array}$ & $\begin{array}{l}\text { In this study } \\
\text { analyzing the } \\
\text { positive or } \\
\text { negative } \\
\text { effects of } \\
\text { variables }\end{array}$ & $\begin{array}{l}\text { Equally } \\
\text { testing } \\
\text { Brand } \\
\text { Trust and } \\
\text { Brand } \\
\text { Loyalty }\end{array}$ \\
\hline 2 & $\begin{array}{l}\text { Nadia } \\
\text { Agustina, } \\
\text { Achmad } \\
\text { Fauzi DH } \\
\text { and Inggang } \\
\text { Perwangsa } \\
\text { Nuralam } \\
(2018)\end{array}$ & $\begin{array}{l}\text { "Effect of } \\
\text { Customer } \\
\text { Satisfaction, } \\
\text { Switching } \\
\text { Costs, and } \\
\text { Brand Trust on } \\
\text { Customer } \\
\text { Loyalty" }\end{array}$ & $\begin{array}{l}\text { There is a } \\
\text { significant } \\
\text { influence } \\
\text { between the } \\
\text { variables of } \\
\text { Customer } \\
\text { Satisfaction, } \\
\text { Switching } \\
\text { Costs, and } \\
\text { Brand Trust on } \\
\text { Customer } \\
\text { Loyalty both } \\
\text { partially and } \\
\text { simultaneously. }\end{array}$ & $\begin{array}{l}\text { This study } \\
\text { examines the } \\
\text { influence and } \\
\text { uses the } \\
\text { independent } \\
\text { variables } \\
\text { consisting of } \\
\text { Customer } \\
\text { Satisfaction, } \\
\text { Switching } \\
\text { Costs, Brand } \\
\text { Trust. While } \\
\text { the dependent } \\
\text { variable is } \\
\text { Customer } \\
\text { Loyalty. }\end{array}$ & $\begin{array}{l}\text { Discuss the } \\
\text { same about } \\
\text { Brand } \\
\text { Trust }\end{array}$ \\
\hline 3 & $\begin{array}{l}\text { Rury } \\
\text { Almadea } \\
(2017)\end{array}$ & $\begin{array}{l}\text { "The Effect of } \\
\text { Service Quality } \\
\text { and Brand } \\
\text { Trust on } \\
\text { Customer } \\
\text { Satisfaction" }\end{array}$ & $\begin{array}{l}\text { There is a } \\
\text { significant } \\
\text { influence } \\
\text { between the } \\
\text { variable Service } \\
\text { Quality and } \\
\text { Brand Trust on } \\
\text { Customer } \\
\text { Satisfaction. }\end{array}$ & $\begin{array}{l}\text { This study } \\
\text { examines the } \\
\text { influence and } \\
\text { uses the } \\
\text { independent } \\
\text { variable } \\
\text { Service } \\
\text { Quality and } \\
\text { Brand Trust, } \\
\text { while the }\end{array}$ & $\begin{array}{l}\text { Discuss the } \\
\text { same about } \\
\text { Brand } \\
\text { Trust }\end{array}$ \\
\hline
\end{tabular}


International Journal of Economics, Business and Accounting Research (IJEBAR)

Peer Reviewed - International Journal

Vol-4, Issue-2, 2020 (IJEBAR)

E-ISSN: 2614-1280 P-ISSN 2622-4771

https://jurnal.stie-aas.ac.id/index.php/IJEBAR

\begin{tabular}{|c|c|c|c|c|c|}
\hline & & & & $\begin{array}{l}\text { dependent } \\
\text { variable is } \\
\text { Customer } \\
\text { Satisfaction. }\end{array}$ & \\
\hline 4 & $\begin{array}{l}\text { Basu } \\
\text { Swastha } \\
\text { Dharmmesta } \\
\text { (1999) }\end{array}$ & $\begin{array}{l}\text { "Customer } \\
\text { Loyalty: A } \\
\text { Conceptual } \\
\text { Study as a } \\
\text { Pandun for } \\
\text { Researchers" }\end{array}$ & $\begin{array}{l}\text { A measure of } \\
\text { loyalty must } \\
\text { refer to } \\
\text { consumers' } \\
\text { interest in a } \\
\text { brand, and the } \\
\text { vulnerability of } \\
\text { consumers to } \\
\text { switch brands } \\
\text { where } \\
\text { consumers have } \\
\text { a positive } \\
\text { attitude towards } \\
\text { the brand to } \\
\text { have a } \\
\text { commitment to } \\
\text { the brand. }\end{array}$ & $\begin{array}{l}\text { In this study } \\
\text { using three } \\
\text { variables, } \\
\text { namely brand } \\
\text { satisfaction, } \\
\text { brand loyalty } \\
\text { and customer } \\
\text { loyalty. }\end{array}$ & $\begin{array}{l}\text { Discuss the } \\
\text { same about } \\
\text { Brand } \\
\text { Loyalty }\end{array}$ \\
\hline 5 & $\begin{array}{l}\text { Jaishankar } \\
\text { Ganesh, } \\
\text { Mark J. } \\
\text { Arnold and } \\
\text { Kristy E. } \\
\text { Reynolds }\end{array}$ & $\begin{array}{l}\text { "Understanding } \\
\text { the Customer } \\
\text { Base of Service } \\
\text { Providers: An } \\
\text { Examination of } \\
\text { the Differences } \\
\text { Between } \\
\text { Switchers and } \\
\text { Stayers". }\end{array}$ & $\begin{array}{l}\text { The analysis } \\
\text { used in testing } \\
\text { hypotheses and } \\
\text { research results } \\
\text { shows lower } \\
\text { satisfaction and } \\
\text { purchase } \\
\text { intention with } \\
\text { brands that } \\
\text { switch to highly } \\
\text { motivated } \\
\text { consumers. }\end{array}$ & $\begin{array}{l}\text { In this study } \\
\text { discusses the } \\
\text { formation of } \\
\text { commitment, } \\
\text { brand trust, } \\
\text { and the } \\
\text { influence of } \\
\text { customer } \\
\text { dissatisfaction }\end{array}$ & $\begin{array}{l}\text { Discuss the } \\
\text { same about } \\
\text { brand trust }\end{array}$ \\
\hline 6 & $\begin{array}{l}\text { Douglas B. } \\
\text { Grisaffe and } \\
\text { Hieu P. } \\
\text { Nguyen } \\
\text { (2011) }\end{array}$ & $\begin{array}{l}\text { "Antecedents of } \\
\text { Emotional } \\
\text { Attachment to } \\
\text { Brands" }\end{array}$ & $\begin{array}{l}\text { Significant } \\
\text { influence about } \\
\text { the antecedents } \\
\text { of brand } \\
\text { construction } \\
\text { that is more } \\
\text { emotional } \\
\text { brand } \\
\text { attachment } \\
\text { shows validity } \\
\text { discrimination } \\
\text { with general } \\
\text { constructs such } \\
\text { as brand } \\
\text { attitude, brand } \\
\text { satisfaction and } \\
\text { brand }\end{array}$ & $\begin{array}{l}\text { This study } \\
\text { uses three } \\
\text { variables, } \\
\text { namely brand } \\
\text { satisfaction, } \\
\text { brand } \\
\text { involvement, } \\
\text { and trust in } \\
\text { the brand. }\end{array}$ & $\begin{array}{l}\text { Discuss the } \\
\text { same about } \\
\text { brand } \\
\text { satisfaction }\end{array}$ \\
\hline
\end{tabular}


International Journal of Economics, Business and Accounting Research (IJEBAR)

Peer Reviewed - International Journal

Vol-4, Issue-2, 2020 (IJEBAR)

E-ISSN: 2614-1280 P-ISSN 2622-4771

https://jurnal.stie-aas.ac.id/index.php/IJEBAR

\begin{tabular}{|c|c|c|c|c|c|}
\hline & & & involvement. & & \\
\hline 7 & $\begin{array}{l}\text { Hasan Afzal, } \\
\text { Muhammad } \\
\text { Aslam } \\
\text { Khan, } \\
\text { Kashif ur } \\
\text { Rehman, } \\
\text { Imran Ali } \\
\text { and Sobia } \\
\text { Wajahat } \\
\text { (2010) }\end{array}$ & $\begin{array}{l}\text { "Consumer's } \\
\text { Trust in the } \\
\text { Brand: Can it } \\
\text { Be Built } \\
\text { through Brand } \\
\text { Reputaion, } \\
\text { Brand } \\
\text { Competence } \\
\text { and Brand } \\
\text { Predictability" }\end{array}$ & $\begin{array}{l}\text { The results } \\
\text { showed that } \\
\text { brand trust } \\
\text { contributed } \\
\text { positively to } \\
\text { brand loyalty. } \\
\text { This is } \\
\text { important for } \\
\text { marketers to } \\
\text { build consumer } \\
\text { confidence in } \\
\text { their brands. } \\
\text { Brand } \\
\text { satisfaction and } \\
\text { brand image are } \\
\text { important in } \\
\text { building and } \\
\text { maintaining } \\
\text { consumer } \\
\text { confidence in } \\
\text { existing brands, } \\
\text { if consumer } \\
\text { trust has been } \\
\text { obtained then } \\
\text { the next thing } \\
\text { the company } \\
\text { must do is } \\
\text { maintain brand } \\
\text { loyalty. }\end{array}$ & $\begin{array}{l}\text { In this study } \\
\text { using the } \\
\text { variable brand } \\
\text { reputation, } \\
\text { brand } \\
\text { predictability, } \\
\text { brand } \\
\text { competence, } \\
\text { and consumer } \\
\text { confidence in } \\
\text { the brand. }\end{array}$ & $\begin{array}{l}\text { Equally } \\
\text { discussing } \\
\text { brand trust } \\
\text { and brand } \\
\text { loyalty }\end{array}$ \\
\hline 8 & $\begin{array}{l}\text { Patricia M. } \\
\text { Doney and } \\
\text { Joseph P. } \\
\text { Cannon } \\
\text { (1997) }\end{array}$ & $\begin{array}{l}\text { "An } \\
\text { Examination of } \\
\text { the Nature of } \\
\text { Trust in Buyers } \\
\text { - Seller } \\
\text { Relationships" }\end{array}$ & $\begin{array}{l}\text { Providing new } \\
\text { insights into } \\
\text { how trust } \\
\text { develops and } \\
\text { how it } \\
\text { influences } \\
\text { industry buying } \\
\text { behavior and } \\
\text { contributes to } \\
\text { the emerging } \\
\text { marketing } \\
\text { liberation of } \\
\text { trust. }\end{array}$ & $\begin{array}{l}\text { This study } \\
\text { uses variable } \\
\text { satisfaction } \\
\text { with the } \\
\text { brand, brand } \\
\text { involvement } \\
\text { and trust in } \\
\text { the brand }\end{array}$ & $\begin{array}{l}\text { Discuss the } \\
\text { same about } \\
\text { brand trust }\end{array}$ \\
\hline 9 & $\begin{array}{l}\text { Kevin Filo, } \\
\text { Daniel C. } \\
\text { Funk, and } \\
\text { Kostas } \\
\text { Alexandris } \\
\\
(2008) \\
\end{array}$ & $\begin{array}{l}\text { "Exploring the } \\
\text { Role of Brand } \\
\text { Trust in } \\
\text { Relationship } \\
\text { Between Brand } \\
\text { Associations } \\
\text { and Brand } \\
\end{array}$ & $\begin{array}{l}\text { The results of } \\
\text { the study } \\
\text { provide support } \\
\text { for hypothesis } 1 \\
\text { in the observed } \\
\text { brand trust to } \\
\text { mediate the }\end{array}$ & $\begin{array}{l}\text { This research } \\
\text { uses brand } \\
\text { trust, brand } \\
\text { association } \\
\text { and brand } \\
\text { loyalty } \\
\text { variables }\end{array}$ & $\begin{array}{l}\text { Equally } \\
\text { testing } \\
\text { brand trust } \\
\text { and brand } \\
\text { loyalty }\end{array}$ \\
\hline
\end{tabular}


International Journal of Economics, Business and Accounting Research (IJEBAR)

Peer Reviewed - International Journal

Vol-4, Issue-2, 2020 (IJEBAR)

E-ISSN: 2614-1280 P-ISSN 2622-4771

https://jurnal.stie-aas.ac.id/index.php/IJEBAR

\begin{tabular}{|l|l|l|l|l|}
\hline & $\begin{array}{l}\text { Loyalty in Sport } \\
\text { and Fitness" }\end{array}$ & $\begin{array}{l}\text { relationship } \\
\text { between the } \\
\text { four brand } \\
\text { associations } \\
\text { and brand } \\
\text { loyalty for } \\
\text { sports brand } \\
\text { samples. }\end{array}$ & & \\
& & & \\
\hline
\end{tabular}

Relationship Between Variables

Relationship between Brand Characteristics and Brand Loyalty

Researchers who have previously discussed the relationship between Brand Characteristics and Brand Loyalty, namely (Mardiah, 2013). The results of his research indicate that Brand Characteristics significantly influence Brand Loyalty.

Relationship between Company Characteristics and Brand Loyalty

From previous research that discusses the relationship between Company Characteristics and Brand Loyalty (Mardiah, 2013) shows that Company Characteristic has a significant effect on Brand Loyalty.

Relationship between Consumer-Brand Characteristics and Brand Loyalty

From previous studies that have discussed the Consumer-Brand Characteristic relationship (Sengkey, 2015), the results show that Consumer-Brand Characteristic has a significant effect on Brand Loyalty.

The following conceptual framework of the set of variables, indicators, and research hypotheses :

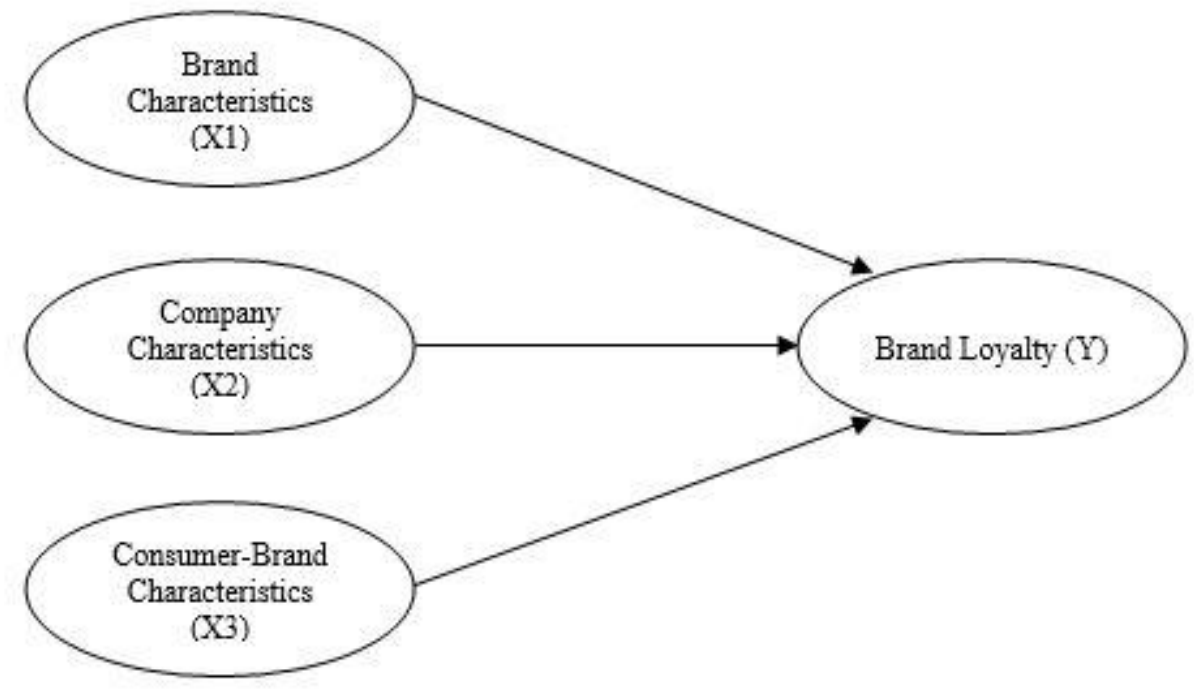

\section{Research Method}

This research was conducted in the Samarinda City in East Kalimantan. Population is a generalization region consisting of object or subject that has certain qualities and characteristics defined by the researchers to learn and then withdrawn conclusion. The population in this study is the consumers of Sarimi products in Samarinda. Samples taken from the entire population are 100 consumers. The sampling method used in this study is the accidental sampling method so that anyone (Sarimi consumers) who accidentally meets the researcher can be used as a sample. Data collection techniques in this study 
International Journal of Economics, Business and Accounting Research (IJEBAR)

Peer Reviewed - International Journal

Vol-4, Issue-2, 2020 (IJEBAR)

E-ISSN: 2614-1280 P-ISSN 2622-4771

https://jurnal.stie-aas.ac.id/index.php/IJEBAR

were carried out by distributing questionnaires (questionnaires), namely collecting data by making a list of questions raised to respondents who have been determined as samples. The type of data used in this study is to use quantitative data in the form of questionnaire tabulation data and qualitative data in the form of a general description of the company. The data source used is the data source that comes from the respondents' questionnaire answers.

This research was measured using a Likert scale (5: 4: 3: 2: 1). Respondents' score scores consisted of strongly agree, agree, disagree, disagree, and strongly disagree. Test data analysis using SPSS by conducting validity tests, reliability tests, descriptive statistical tests, correlation analysis tests, and multiple linear analysis tests.

4. Result

Table 1. ANOVA

\begin{tabular}{|c|l|r|r|r|r|c|}
\hline \multicolumn{2}{|c|}{ Model } & $\begin{array}{c}\text { Sum of } \\
\text { Squares }\end{array}$ & df & $\begin{array}{c}\text { Mean } \\
\text { Square }\end{array}$ & F & Sig. \\
\hline \multirow{2}{*}{1} & Regression & 18,014 & 3 & 6,005 & 7,396 &, $000 \mathrm{~b}$ \\
\cline { 2 - 7 } & Residual & 77,946 & 96 &, 812 & & \\
\cline { 2 - 7 } & Total & 95,960 & 99 & & & \\
\hline
\end{tabular}

Table 2. Coefficients

\begin{tabular}{|l|l|r|r|r|}
\hline \multicolumn{2}{|l|}{ Model } & $\begin{array}{c}\text { Standardized } \\
\text { Coefficients }\end{array}$ & \multirow{2}{*}{ t } & \multirow{2}{*}{ Sig. } \\
\cline { 3 - 5 } \multicolumn{2}{|c|}{1} & Beta & & \\
\cline { 2 - 5 } & Brand Characteristics &, 061 &, 649 &, 693 \\
\cline { 2 - 5 } & $\begin{array}{l}\text { Company } \\
\text { Characteristics }\end{array}$ &, 198 & 2,003 &, 048 \\
\cline { 2 - 3 } & $\begin{array}{l}\text { Consumer-Brand } \\
\text { Characteristics }\end{array}$ &, 302 & 3,028 &, 003 \\
\hline
\end{tabular}

The table mentioned above titled coefficients helps to see which of the three dependent variables most influences. On Brand Characteristics variable, the result of sig. 0.518> 0.05 and t count $0.649<\mathrm{t}$ table 1.984 , it can be concluded that the Brand Characteristics variable has no influence on Brand Loyalty.

The Company Characteristics variable produces sig values. $0.048<0.05$ and t count 2.003> t table 1.984, it can be concluded that there is an influence between Company Characteristics and Brand Loyalty. The Consumer-Brand Characteristics variable produces sig values. $0.003<0.05$ and tcount $3.028>\mathrm{t}$ table 1.984 , it can be concluded that there is an influence between Consumer-Brand Characteristics and Brand Loyalty.

\section{Conclusions and Suggestions}

\section{Conclusions}

Based on the results of the previous analysis and discussion, the following conclusions are made:

a. Brand Characterist has no significant effect on Brand Loyalty.

b. Company Characteristics has significant effeect on Brand Loyalty.

c. Consumer-Brand Characteristics has significant effect on Brand Loyalty.

\section{Suggestions}


International Journal of Economics, Business and Accounting Research (IJEBAR)

Peer Reviewed - International Journal

Vol-4, Issue-2, 2020 (IJEBAR)

E-ISSN: 2614-1280 P-ISSN 2622-4771

https://jurnal.stie-aas.ac.id/index.php/IJEBAR

Based on the assessment of researchers' results in the field, the authors intend to provide suggestions that are expected to benefit the company and subsequent researchers:

a. For companies

To maintain and maintain brand loyalty, companies must maintain reputation and find ways to continue creating innovations that customers need. Companies also need to pay attention to changes in consumer tastes and choices, the emergence of new competitors or new developments in the marketing environment.

b. For Future Researchers

It is expected that further researchers can examine more sources related to the relationship of brand characteristics, company characteristics, and consumer-brand characteristics with brand loyalty so that research results can be better. And prepare yourself in the process of taking and collecting data so that research is well and it is also hoped that further researchers can use interviews with Sarimi consumers.

\section{References}

Afzal, H., Khan, MA, \& Rehman, K. ur. (2010). Consumer's Trust in the Brand: Can it Be Built through Brand Reputation, Brand Competence and Brand Predictability. International Business Research , 3 (1), 43-51.

Agustina, N., DH, AF, \& Nuralam, IP (2018). Effect of Customer Satisfaction, Switching Costs, and Brand Trust on Customer Loyalty. Journal of Business Administration (JAB) , 64 (1), 92-101.

Almadea, R. (2017). Effect of Service Quality and Brand Trust on Customer Satisfaction (Study on Customers of BNI Syariah Bank Funds Collecting Products) Pekanbaru Branch Office. JOM FISIP , 4 (2), 1-10.

Dharmmesta, BS (1999). Customer Loyalty: A Conceptual Study As A Guide For Researchers. Indonesian Journal of Economics and Business, 14 (3).

Doney, PM, \& Cannon, JP (1997). An Examination of the Nature of Trust in Buyer-Seller Relationships. Journal of Marketing , 61, 35-51.

Ganesh, J., Arnold, MJ, \& Reynolds, KE (2000). Understanding the Customer Base of Service Providers: An Examination of the Differences Between Switchers and Stayers. Journal of Marketing , 64, 65-87.

Grisaffe, DB, \& Nguyen, HP (2011). Antecedents of Emotional Attachment to Brands. Journal of Business Research , 64 (10), 1052-1059.

Lau, GT, \& Lee, SH (1999). Consumers' Trust in a Brand and the Link to Brand Loyalty. Journal of Market Focused Management , 4 , 341-370.

Mardiah, A. (2013). The Influence of Brand Characteristics and Company Characteristics on Brand Loyalty on Sophie Martin Bag Customers in Pekanbaru City. Journal of Computer and Business Science, 4 (1).

Nunnally, JC (1975). Psychometric Theory - 25 Years Ago and Now. Educational Researcher , 4 (10), 7-21.

SA, S. (2008). Fundamentals of Brand Management (1st ed .; S. Wahyudi, Y. Setyorini, \& I. Basuki, Eds.). Malang: Bayumedia Publishing.

Sengkey, KF (2015). Influence of Brand Characteristics, Company Characteristics, and Brand Characteristics on Consumers of Brand Trust in Bellagio Shoes Products in Manado. EMBA Journal , 3 (3), 341-351.

Veloutsou, C., \& Moutinho, L. (2009). Brand Relationships Through Brand Reputation and Brand Tribalism. Journal of Business Research, 62 (3), 314-322.

Wang, ZF, Wu, WY, \& Lin, C. (2000). A study of market structure: brand loyalty and brand switching behavior for durable household appliances. International Journal of Market Research , 42 (3), 1-16. 